\title{
Analysis of Radionuclide Concentrations and Movement Patterns of Hanford Site Mule Deer
}
L. E. Eberhardt
E. E. Hanson
L. L. Cadwell

October 1982

Prepared for the U.S. Department of Energy under Contract DE-AC06-76RLO 1830

Pacific Northwest Laboratory Operated for the U.S. Department of Energy by Battelle Memorial Institute 


\title{
DISCLAIMER
}

This report was prepared as an account of work sponsored by an agency of the United States Government. Neither the United States Government nor any agency thereof, nor any of their employees, makes any warranty, express or implied, or assumes any legal liability or responsibility for the accuracy, completeness, or usefulness of any information, apparatus, product, or process disclosed, or represents that its use would not infringe privately owned rights. Reference herein to any specific commercial product, process, or service by trade name, trademark, manufacturer, or otherwise, does not necessarily constitute or imply its endorsement, recommendation, or favoring by the United States Government or any agency thereof. The views and opinions of authors expressed herein do not necessarily state or reflect those of the United States Government or any agency thereof.

\author{
PACIFIC NORTHWEST LABORATORY \\ operated by \\ BATTELLE \\ for the \\ UNITED STATES DEPARTMENT OF ENERGY \\ under Contraci DE-AC06-76RLO 1830
}

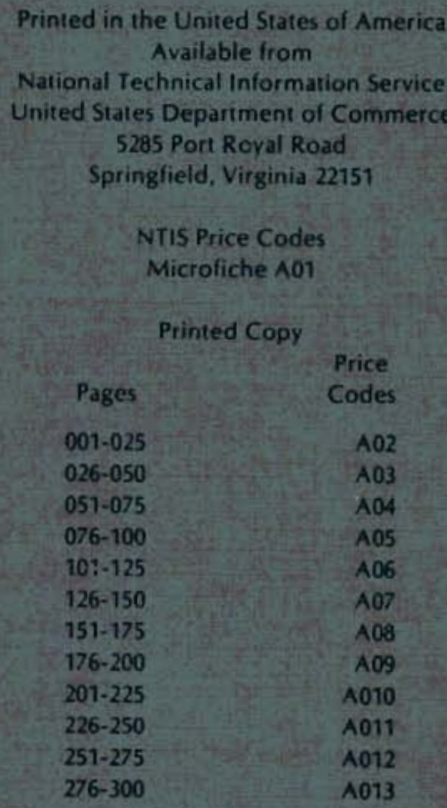


PNL -4420

UC-41

ANALYSIS OF RADIONUCLIDE CONCENTRATIONS

AND MOVEMENT PATTERNS OF HANFORD SITE MULE DEER
L. E. Eberhardt
E. E. Hanson
L. L. Cadwe 11

October 1982

Prepared for

the U.S. Department of Energy

under Contract DE-AC06-76RLO 1830

Pacific Northwest Laboratory

Richland, Washington 99352 


\section{ACKNOWLEDGMENTS}

This study was conducted by the Pacific Northwest Laboratory (PNL) (a) and jointly funded by the Environmental Surveillance Program of the U.S. Department of Energy's (DOE) Richland Operations Office and the Radioecology of Nuc lear Fuel Cycles program of DOE's Office of Health and Environmental Research. The Washington State Game Department provided permits to conduct the study and several of its personnel (D. N. Flohr, T. A. Clausing, and J. McIntosh) assisted in deer-capture efforts. The California Fish and Game Department's wildlife investigations laboratory analyzed deer blood samples for several diseases, and two of its personnel, D. A. Jessup and W. Clark, were instrumental in implementing the mass capture technique. NORCUS program students, S. A. Eisner, B. L. Biswell and D. Elwood conducted much of the field work. PNL veterinarians, S. E. Rowe, R. A. Miller, and R. A. Renne assisted in deer-capture efforts and $M$. Giles obtained tranquilizing drugs. We greatly apprecate the help from other Hanford site personnel who assisted in the deercapture efforts. Computer analysis of deer home range was conducted by G. C. White, Los Alamos National Laboratory. R. E. Austin and K. R. Price assisted throughout all phases of the study. K. R. Price and M. J. Sula reviewed a draft of this report.

(a) Operated by Battel le Memorial Institute for DOE. 


\section{SUMMARY AND CONCLUSIONS}

From 1980 through 1982, the movements of 37 radio-collared mule deer (0docoileus hemionus) were monitored for periods of 3 to 17 months on the Hanford Site in southcentral Washington. The objectives were to compare radionuclide concentrations in deer residing near the 200 Area waste management sites with concentrations in deer occupying areas remote from waste management sites and to document movement patterns of Hanford Site deer with particular emphas is on offsite movements.

Seventeen radio-collared animals of known residence history were collected for radiological examination, 12 from the 200 Area and 5 control animals from Hanford Site areas remote from waste management zones. Cesium-137 in deer muscle and liver and ${ }^{90} \mathrm{Sr}$ concentrations in deer bone were statistically higher in deer living near the 200 Area than in control animals. However, radionuclide concentrations in deer from both locations were lower than values observed in the past for deer from the Hanford Site and other DOE facilities. During this study, the highest concentrations of ${ }^{137} \mathrm{Cs}$ and ${ }^{90} \mathrm{Sr}$ in 200 Area deer were in those individuals residing in or immediately adjacent to radiation zones.

Cesium-137 and ${ }^{90}$ Sr concentrations were more variable in deer residing near the 200 Area than in control animals, where only background (fallout) levels were observed. This variability was, presumably, related to many factors, including a nonuniform distribution of contaminants in the environment, nonuniform habitat usage by deer, and differences in behavioral patterns of individual animals. A comparison of the distance individual 200 Area deer resided away from Gable Mountain Pond and the proportion of time individual animals spent near defined radiation zones revealed that both values (distance and proportion of time) were significantly correlated with radionuclide concentrations.

Movement patterns of Hanford site deer were analyzed to determine home range size and usage. The average home range was $0.39 \pm 27 \mathrm{~km}^{2}$; however, some areas within the home range were used more intensely than others. In 
addition, ten (27\%) of the monitored deer made offsite movements during the study period. While most of these movements were made in the spring and summer, some fall and winter movements were noted.

Radiotelemetry monitoring also helped identify the approximate number of deer being harvested each year. Two of the 200 Area deer that moved offsite were harvested, one legally and one apparently illegally. Based on this small sample size, it was estimated that approximately $8 \%$ (95\% confidence interval is from 0 to $21 \%$ ) of the Hanford deer herd is harvested each year. As a result of the low harvest rate, the Hanford deer herd appears to have a disproportionate number of older animals, with $24 \%$ of the 17 examined deer older than 10.5 years. 


\section{CONTENTS}

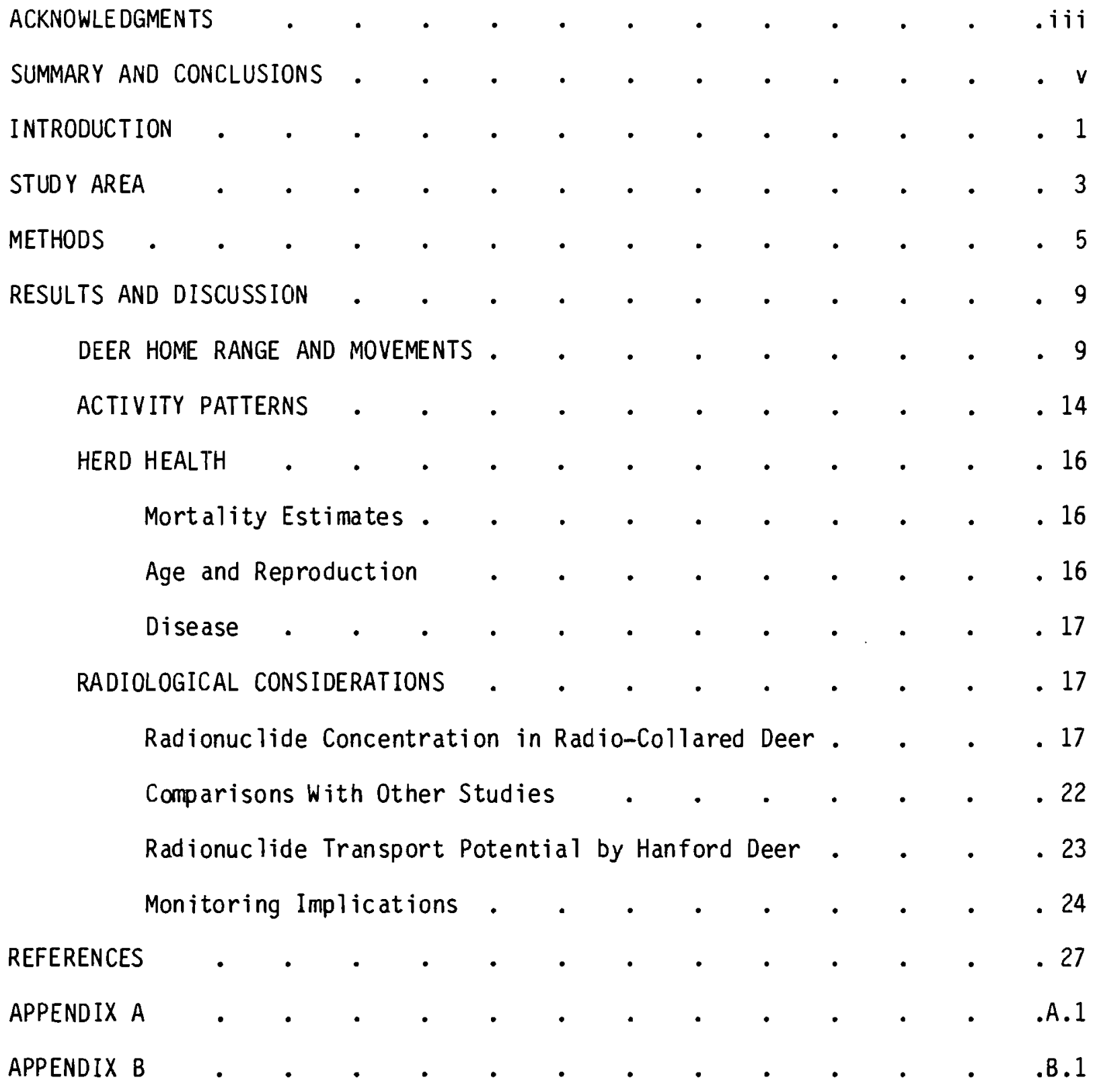




\section{FIGURES}

1 Study Area and Mule Deer Capture Locations . $\quad$. $\quad$. $\quad$. $\quad$. 4

2 Movement of Radio-Collared Mule Deer Off the Hanford Site . . . 13

3 Activity Pattern of Hanford Site Deer as Measured by Average Distance Moved per Hour • • • • • • • . . . 15

\section{TABLES}

1 Home Range Size Estimates for 34 Mule Deer on the Hanford Site . . 10

2 Concentrations of ${ }^{137} \mathrm{Cs}$ in the Muscle and Liver and $90 \mathrm{Sr}$ in the Bone of 17 Radio-Collared Deer Collected on the

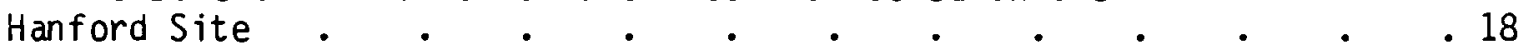

3 Correlation $\left(r^{2}\right)$ of Radionuclides in Deer Tissue With Proportions of Time Deer Spent Near Radiation Zones and with Distances Deer Resided from Gable Pond . . . . . . . 21

4 Cesium-137 Concentrations in Muscle of Mule Deer from

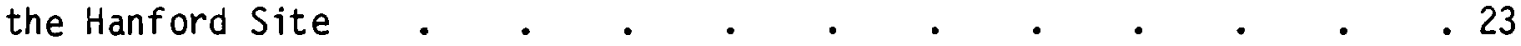

B-1 Comparison of Home Range Sizes Obtained by Three Estimation Techniques for Four Closely Associated Hanford Site Deer . . . . . .1 


\section{INTROOUCTION}

Mule deer (0docoileus hemionus) are an important and conspicious part of the biota of the Hanford Site in southcentral Washington where a variety of nuclear facilities including reactors, chemical processing facilities, and waste disposal sites are located. The routine monitoring of radionuclides present in deer killed by vehicles on Hanford Site roads (Sula et al. 1982) and past analyses of deer collected on the Hanford Site (Eberhardt et al. 1969, Uresk and Uresk 1980) have indicated that the levels of radionuclides in deer tissue were generally not appreciably greater than expected from natural or fallout contribution sources. However, it is difficult to interpret radionuclide data collected in previous studies because deer are a highly mobile species and the amount of time sampled individuals spent in waste management sites is unknown. Markham et al. (1982) reported a similar problem at the Idaho National Engineering Laboratory.

Bec ause it is unclear whether the deer sampled in these previous studies were exposed to contaminated areas on the Hanford Site, PNL conducted a special study with the primary objectives of: (1) obtaining movement data on Hanford Site deer, particularly 200 Area animals, to determine whether they disperse to surrounding public and private lands where they are available for harvesting by man and (2) evaluating radionuclide concentrations in deer residing near the 200 Area waste management sites compared to concentrations in Hanford Site deer occupying areas remote from waste management activities. A secondary objective of this study was to collect information on the health and activities of Hanford Site deer and compare this data with published information on offsite deer populations.

The information contained in this report identifies the range of radionuclide concentration data for Hanford deer and provides a basis for trend analysis with future monitoring data. The methodologies (applications of radiotelemetry to monitoring) provide a useful tool for determining representative estimates of contaminant concentrations in mobile species. Lastly, the movement and activity data obtained for 200 Area deer can provide a sound 
scientific basis for evaluating potential impacts in the unlikely event of an accidental spread of contamination in the environs of the 200 Areas and is also useful in evaluating and designing alternative deer sampling techniques for the routine environmental wildlife monitoring program on the Hanford Site. 


\section{STUDY AREA}

The study was conducted from 1980 through 1982 on that portion of the Hanford Site bordered by State Highway 240 on the south and west and the Columbia River on the north and east (Figure 1). The Hanford Site was established in 1943 as a national security area and has been closed to public access since that date. The area is characterized by steppe vegetation, sagebrush (Artemisia tridentata)/grass (Daubenmire 1970), and an arid climate with approximate1y $16 \mathrm{~cm}$ of annual precipitation (Thorp and Hinds 1977). The climate consists of hot, dry sumers and relatively cool winters.

Deer were studied in two general areas, one along the western shoreline of the Columbia River and the other in the vicinity of the manmade 200 Area waste management ponds, Gable Pond and B Pond (Figure 1). These areas correspond to those regions believed to have the highest deer concentrations on the Hanford Site. Deer are presumably attracted to these areas bec ause of better habitat conditions and the availability of water. The manmade ponds have undergone ecological succession and now support dense stands of aquatic and riparian species (Rickard, Fitzner and Cushing 1981).

Both ponds receive effluent water from chemical and waste processing facilities in the 200 East Area, which contains very low-level radioactive contaminants (National Academy of Sciences 1978). Past unplanned releases plus the routine low-level discharge have resulted in some accumulation of radionuclides in pond sediments. Low-level contaminants have also been reported in some animals known to frequent the ponds (Cushing and Watson 1974; Cadwell, Schreckhise and Fitzner 1979; Rickard, Fitzner, and Cushing 1981). 


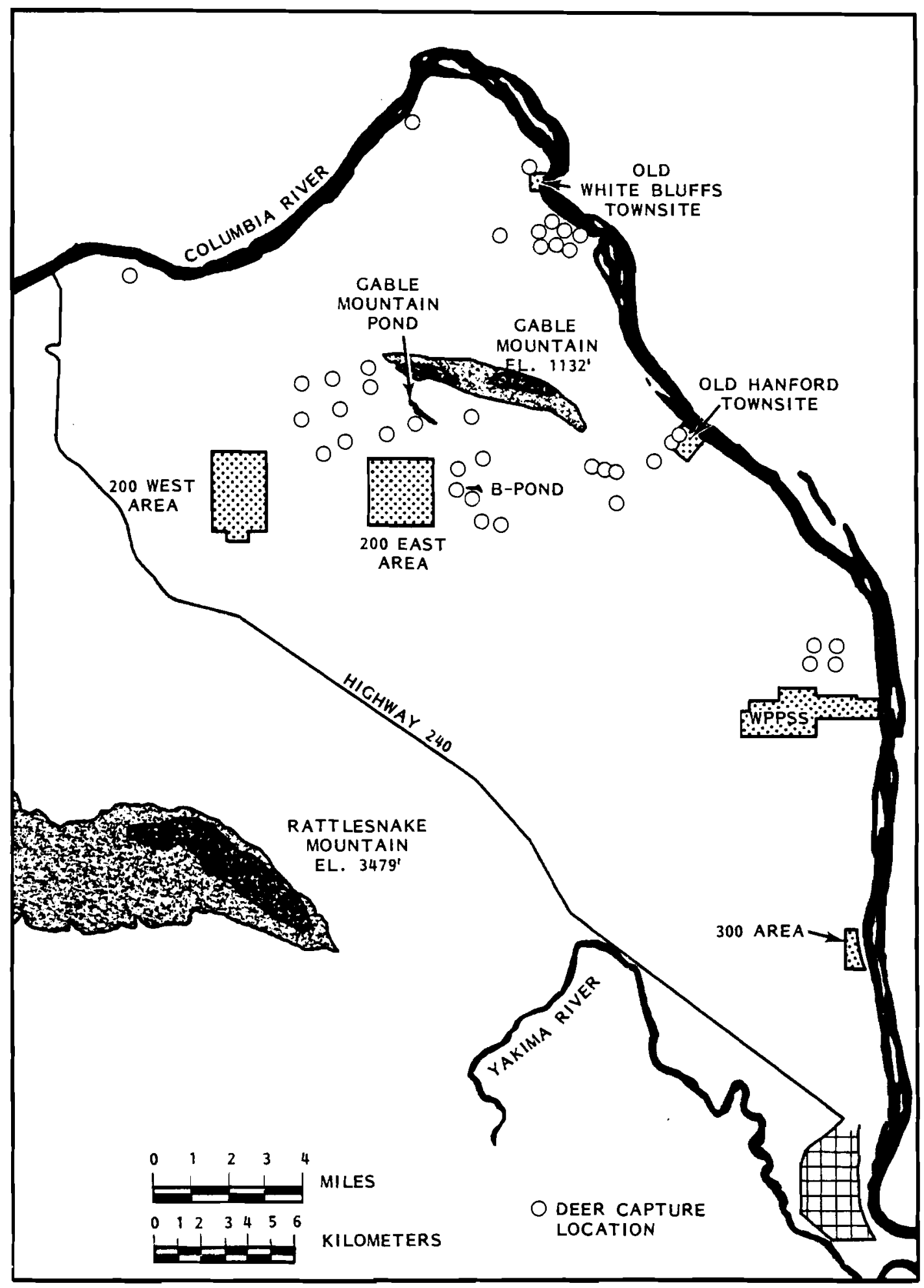

FIGURE 1. Study Area and Mule Deer Capture Locations 


\section{METHODS}

Deer were captured by chemical immobilization using a rifle-fired dart or a mass $c$ apture technique employing a helicopter and drive nets. A combination of etorphine hydrochloride (M-99), xylazine (Rompun), and hyaluronidase (Wydase) was used for chemical immobilization. The mass capture technique described in detail by Beasom, Evans and Temple (1980), involved stringing six 30.5-m sections of 2.4-m-high nylon net in a continuous line, generally in an "L" configuration near a herd of deer. The deer were then guided by a helicopter into the net and were then physically restrained by capture personnel. All captured adult and some juvenile ( $>6$ months old) deer were fitted with a radio transmitter operating on $148 \mathrm{MHz}$, injected with a long acting antibiotic (Flocillin), and released. The radio transmitters weighed between 400 and $500 \mathrm{~g}$ and were manufactured by the University of Minnesota or Telonics, Inc. Blood samples were taken from some deer for disease analysis.

Radio-equipped deer were relocated from the ground or air. Either a truck equipped with a rotatable single Yagi antenna or a hand-held Yagi antenna was used in radio-tracking from the ground. A Cessna 172 fitted with two Yagi antennas was used for relocations from the air. Location error was estimated to be between 0 and $300 \mathrm{~m}$ for ground tracking and between 0 and $200 \mathrm{~m}$ for aerial tracking. All deer locations were plotted on grided U.S. Geological Survey maps (scale 1:63,000) or aerial photos. Plots of the deer locations and home range estimates were obtained from computer programs developed at the University of Minnesota (Siniff 1966) and modified by Gary C. White, Los Alamos National Laboratory.

Home range estimates were obtained by three techniques: the minimum convex polygon (Odum and Kuenzler 1955), grid square (Siniff and Tester 1965), and the 95\% confidence interval ellipse (Jennrich and Turner 1969). The minimum convex polygon option calculates the area contained within the smallest possible convex polygon that $c$ an be fitted around the outer most animal positions. The grid square method essentially overlays the animal's home range with grid squares of a specified size ( 20 ha for 200 Area deer and 100 ha for 
non-200 Area deer in our case) and sums the number of squares that contain at least one relocation. The elliptical technique fits a $95 \%$ confidence ellipse on the area used by an animal.

Radio-collared deer residing near the 200 Area were systematically relocated three days a week at random times during the day. Marked deer residing el sewhere on the Hanford Site were relocated at least once a week on a systematic basis. In addition, selected deer were followed for extended periods of time, 3 to 9 hours, throughout the study to obtain information on activity patterns and habitat use. Positional data collected during extended periods of tracking were excluded in home range size calculations since it disproportionally distorted the number of relocations made on some individuals which in turn affected home range size (Macdonald, Ball, and Hough 1980). Confidence 1 imits for the proportion of time deer spent near the waste ponds were obtained from the following formulas (Snedecor and Cochran 1980, page 121):

$$
\begin{aligned}
& \hat{p}=\frac{r}{n} \\
& \hat{p} \pm[1.96 \sqrt{(\hat{p} \hat{q} / n}+1 /(2 n)]
\end{aligned}
$$

where: $\hat{p}=$ est imate of proportion of time deer spent near waste sites

$\hat{q}=1-\hat{p}$

$r=$ number of times deer were loc ated near waste sites

$n=$ total number of times waste sites were searched for deer.

Selected deer that lived near B and Gable Mountain Ponds for at least $70 \mathrm{~d}$ based on radio-tracking data were sacrificed and analyzed for radionuclides. A 70-d period was selected as the minimum required residence time for deer since it is the approximate time necessary to ensure that the ${ }^{137} \mathrm{Cs}$ (the predaninant expected radionuclide) concentration in collected deer tissue was near equilibrium with the surrounding environment. This time period is based on the equation presented in Davis and Foster (1958) for calculating the amounts of 
radionuclides present in organisms resulting from food consumption and on an approximate $14-d$ biological half-time for ${ }^{137} \mathrm{Cs}$ in mule deer (Hakonson and Wicker 1969). The equation in Davis and Foster (1958) is:

$$
\frac{Q_{t}}{Q_{\varepsilon}}=1-e^{-\lambda t}
$$

where:

$Q_{\varepsilon}=$ the amount of radionclide present at equilibrium

$Q_{t}=$ the amount of radionuclide present at some time $t$ before equilibrium is reached ( $Q t$ approaches $Q t \in$

$\lambda=$ radioactive decay constant $\left(\frac{0.693}{\text { biological half-time }}\right)$.

We used a practical equilibrium ( $Q_{t}$ when $t$ is large relative to half-time) of five retention half-times or $97 \%$ of true equilibrium $\left(Q_{\varepsilon}\right)$. Therefore practical equilibrium is reached in $70 \mathrm{~d}$ ( 5 half-times $\times 14-d$ half-times).

Samples including muscle, rumen contents, liver, thyroid, leg bone, and lower jaw were collected. Thyroid and rumen samples were processed and stored for future analysis. The lower jaw was used to estimate age of the collected deer (Taber 1969). Muscle and liver samples were oven dried at $55^{\circ} \mathrm{C}$ for at least $48 \mathrm{~h}$ and ground in a Wiley mill. The average dry-to-wet weight conversion factor for deer muscle was 0.264 . Muscle and liver samples were then compressed into 60-g pel lets with a binder (cellulose) material added and analyzed for gamma-enitting radionuclides with a GeLi detector-multichannel analyzer system. Bone samples were analyzed for ${ }^{90}$ Sr content by standard radiochemical procedures (U.S. Testing, Inc. 1980). Muscle samples from road-killed deer were analyzed on a continuing basis for gamma emitting radionuclides by U.S. Testing (on a wet weight basis with a sodium iodide detector) as part of the routine environmental monitoring program. 
RESULTS AND DISCUSSION

Thirty-nine deer ( 27 adult females, 3 juvenile females, 6 adult males, and 3 juvenile males) were captured and fitted with radiocollars during the study. Capture locations are plotted in Figure 1. Transmitters quit functioning on two of the deer shortly after installation and data from these animals were excluded from the analysis.

\section{DEER HOME RANGE AND MOVEMENTS}

The 37 deer were reloc ated 1,911 times (excludes data collected during extended tracking periods) for an average of $51 \pm 25$ [1 standard deviation (SD) ] relocations/deer (range 24 to 150). Individual animals were tracked from 3 to 17 months $(\bar{X}=7.9 \pm 4.7)$. Total monitoring time represented 24.75 deeryears. Area estimates of deer home ranges, that is, the area used by an animal during its normal daily activity (Burt 1943), are summarized in Table 1 (see Appendix A for individual values). Three deer (Nos. 567,890,935) left the study area soon after they were captured and are not included in the home range analysis.

Based on the elliptical technique of home range estimation (see Methods and Appendix $B$ ) the average hame range size for Hanford Site deer was $39 \pm 27 \mathrm{~km}^{2}$ (range 4 to $89 \mathrm{~km}^{2}$ ). This average value is considerably larger than reported in studies of mule deer in other locations (Zalunardo 1965; Robinette 1966; Eberhardt and White 1979). However, differing methods of data collection and analysis, different habitats, and length of study, all of which affect home range size estimates, may make such comparisons of limited value. No significant $(p=0.48)$ difference was observed in home range size for male and female deer at Hanford $(t=0.716, d . f .=32$, for Student's $t$-test assuming equal variances based on $F$ - test of variances), although other investigators at other sites have reported that males are more mobile than females (Dasmann and Taber 1956; Robinette 1966).

Factors influencing home range usage patterns are not clearly understood, nor was it an objective of this study to identify such factors. However, local habitat quality, physical terrain features, and water availability may have 


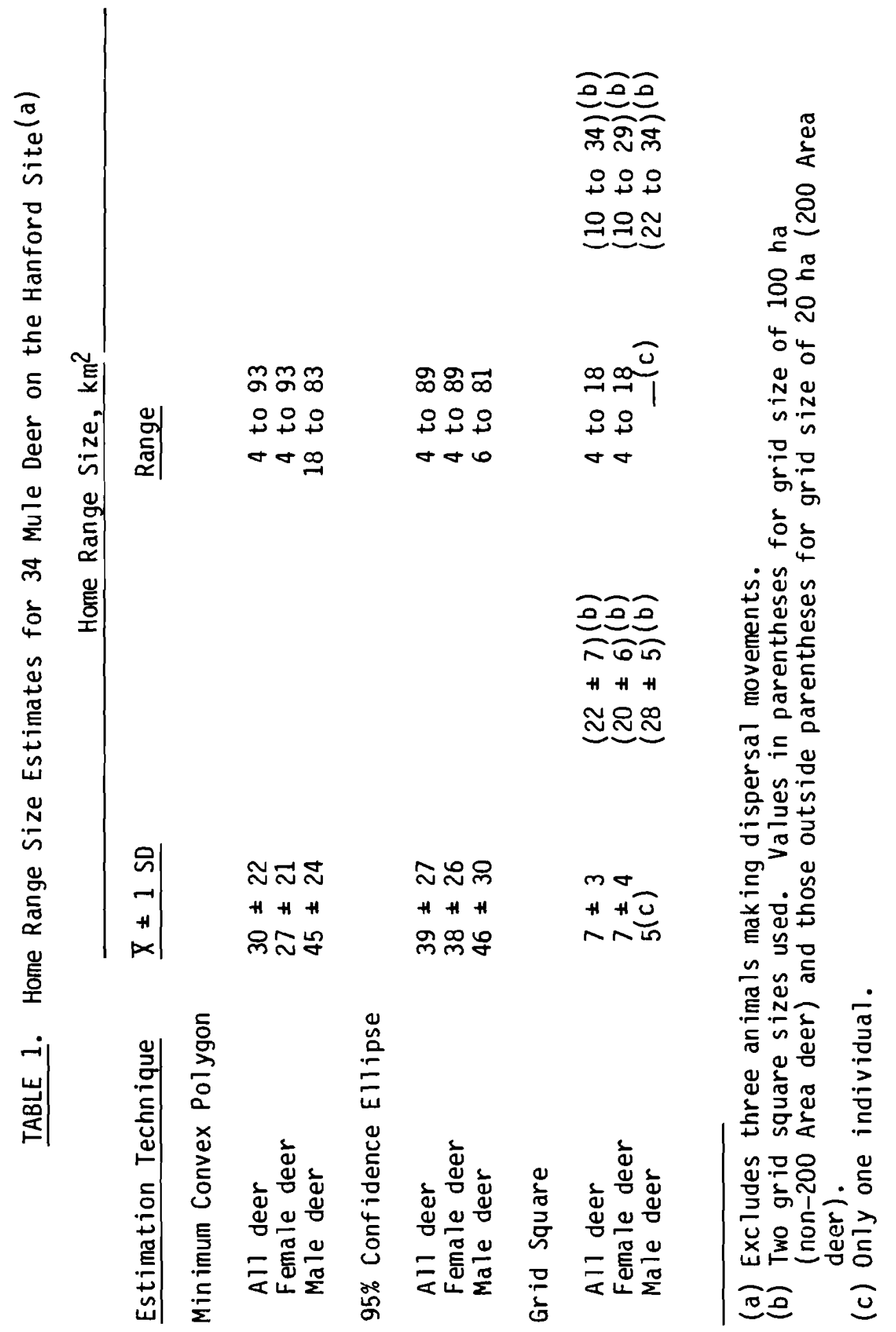


influenced the area used by Hanford deer. Radio-collared deer did not use their home range in a uniform pattern. Deer would use a small area intensively for a period of time ranging from a few days to several months and then move to another area. Nonuniform home $r$ ange use has been observed elsewhere for mule deer (Dasman and Taber 1956; Eberhardt and White 1979) and white-tailed deer (Odocoileus virginianus) (Rongstad and Tester 1969; Sparrowe and Springer 1970; Drolet 1976). Trees, although relatively rare on the Hanford Site, appeared to attract deer and to influence their home range usage patterns. Areas near the old townsites of Hanford and White Bluffs, as well as an old orchard near the 100-D Area, were heavily used by deer. The availability of free water also may have affected home range usage patterns by Hanford deer. Deer densities (based on observations) appeared to be relatively high along the Columbia River and near the Gable and B-Pond areas, which represent the major sources of free water available to deer in the study area. We did not, however, observe directional movements of collared deer or a shifting of overall activity by deer to these water sources during the dry summer months. Two deer (Nos. 530 and 830) occupied an area devoid of free water midway between B Pond and the Columbia River during July and August and did not appear to make regular movements to either water source despite the fact that these animals were intensively tracked (ten, 6-to 8-h-long tracking periods in addition to the $r$ andom relocations three days a week). Deer are reported to require free water regularly during periods of high ambient temperatures and low availability of succulent vegetation (Short 1981). It is unknown whether we failed to detect movements to water through inadequate sampling or whether deer were obtaining sufficient water from their forage despite the fact that most vegetation is relatively dormant during this season on the Hanford Site.

The Columbia River was not a barrier to deer movements, although undoubtedly it did restrict the free movement of deer residing along the shoreline. Of the 14 deer residing along the river, six (43\%) swam across the river or moved to islands at some period during the study. Eight (22\%) of the 37 monitored deer (river and inland animals) made at least one trip across the river. Deer No. 755 swam across the river and back a minimum of eight times during 19 months of tracking. Other investigators have shown that mule deer 
(Robinette 1966) and white-tailed deer (Inglis et a1. 1979) regularly cross large bodies of water. None of the deer monitored during our study appeared to use the Columbia River islands as fawning sites, although such use by Hanford deer is common (Hedlund 1975; Steigers 1978; Eberhardt, Hedlund, Rickard 1979).

Some Hanford deer showed a marked fidelity to a particular area. Deer Nos. 770 and 755 were both ear-tagged as fawns seven and eight years earlier (Hedlund 1975; Eberhardt, Hedlund, Rickard 1979), respectively, in the same area that they were captured and radio-collared as adults during our study. Other deer (Nos. 567, 890, and 935), however, dispersed from the area we originally captured them in during our investigation (Figure 2). These animals, one 2-year old male and two 1-year old females moved frcm 19 to $25 \mathrm{~km}$ during dispersal. These movements were made between early May and early July, a period of time when adult females are having young and are aggressive toward associated yearlings (Linsdale and Tomich 1953; Geist 1981).

At least seven of the 37 monitored deer (19\%) wandered temporarily outside their normal home range and subsequently returned. These apparent erratic movements, called "trips" by Inglis et al. (1979) for white-tailed deer, ranged up to $20 \mathrm{~km}$ from home range centers and lasted from a few hours to several days. Trips and dispersal type movements did not appear to be related to capture activities as noted elsewhere by Robinette (1966) and Eberhardt and White (1979). Those movements took place several months following capture and did not appear to be triggered by our radiotelemetry monitoring activities.

Ten radio-collared deer (27\%) made movements off the Hanford Site during 24.75 deer-years of monitoring if both dispersal and trip movements are considered (Figure 2). These movements were made in all directions from the Hanford Site and ranged up to $7 \mathrm{~km}$ beyond Hanford Site boundaries. Offsite movements of up to $113 \mathrm{~km}$ were recorded during a study of 346 fawns ear-tagged on islands and shoreline habitat associated with the Columbia River (Eberhardt, Hedlund, and Rickard 1979). Offsite movements by deer during our study were typically made during the spring and summer, although a few were made in the fall and winter months. 


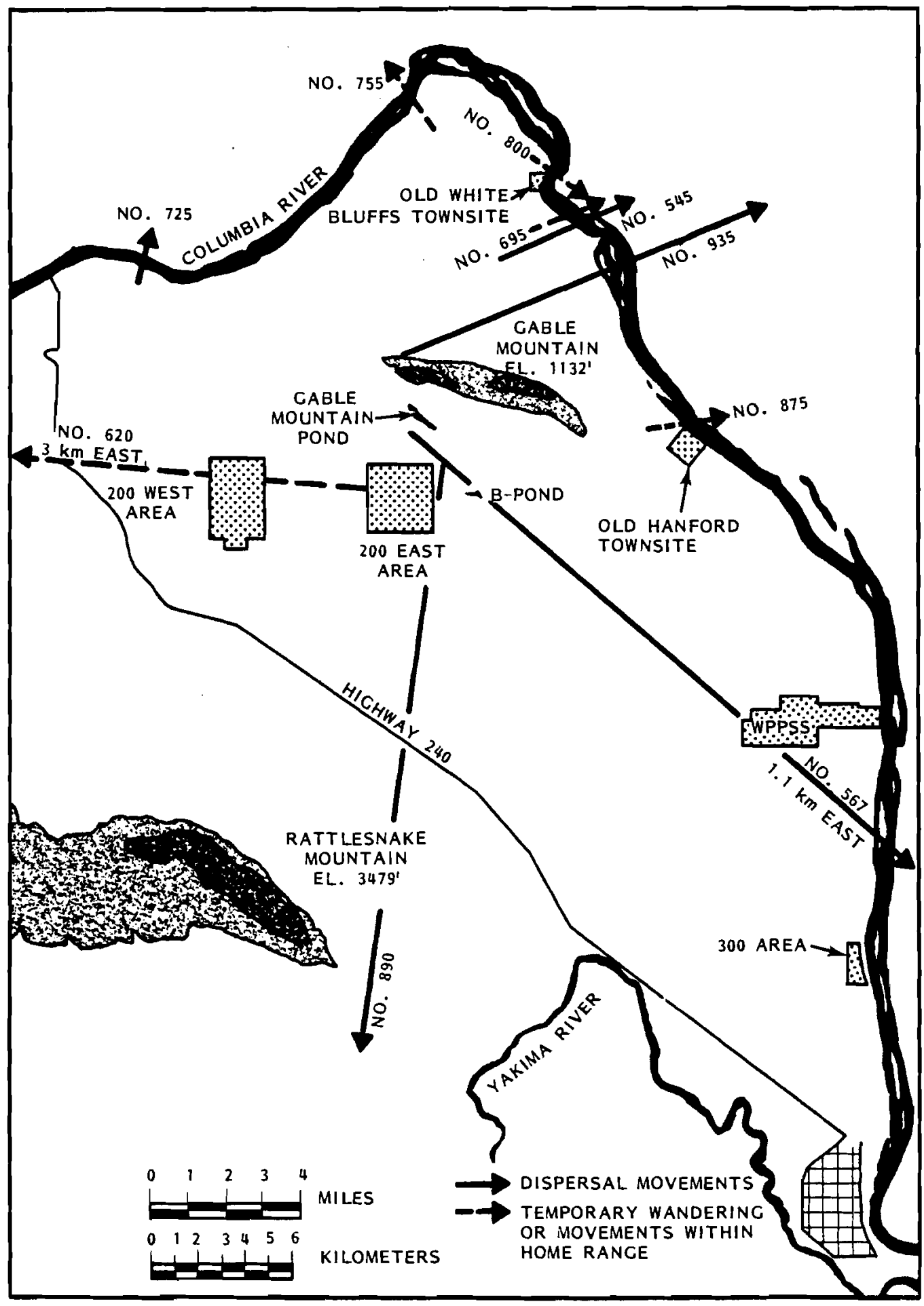

FIGURE 2. Movement of Radio-Collared Mule Deer Off the Hanford Site 


\section{ACTIVITY PATTERNS}

The average distance moved per hour by radio-collared deer was used as a measure of deer activity. This information was based on 205, 2- to 9-h-long radio-tracking sessions on individual animals. A plot of the distance moved per hour by deer versus the time of day is presented in Figure 3 and uses data from all deer and all seasons. Two peaks in activity were observed, one in the morning and another in the evening. The peak in activity recorded between 2300 and $2400 \mathrm{~h}$ is probably due to the sma 11 number of samples from this period. Similar morning and evening peaks in activity were observed on a seasonal (summer, fall, and winter) basis. Crepuscular (twilight) activity patterns have been observed elsewhere for mule deer (Miller 1970) and white-tailed deer (Kammermeyer and Marchinton 1977), although relatively little quantitative data are available.

The average distance moved per hour by deer was $205 \pm 409 \mathrm{~m}$. Males appeared to move greater average distances $(\bar{X}=280 \pm 517 \mathrm{~m} / \mathrm{h}, N=268$ observations) than females $(\bar{X}=183 \pm 368 \mathrm{~m}, N=881$ observations $)$; however, the correlated nature of the data, that is, what a deer was doing one hour during monitoring was likely to have influenced what it was doing the next, makes standard statistical comparisons difficult. The mean distance moved per hour by deer during the sumer, fall, and winter was $211 \pm 459(\mathrm{~N}=831), 274 \pm 307$ $(\mathrm{N}=93)$, and $158 \pm 185(\mathrm{~N}=224) \mathrm{km}$, respectively. Again, the correlated nature of the data prohibits standard statistical tests. However, if the differences in the mean distance moved are real, our data would compare with that of Kammermeyer and Marchington (1977), who found that the mean distance moved per time period by white-tailed deer was greater in the fall than summer. This activity was due, at least in part, to fall breeding activities. The variability in movements by Hanford Site deer appeared to be greater in the summer than in the fall and winter. 


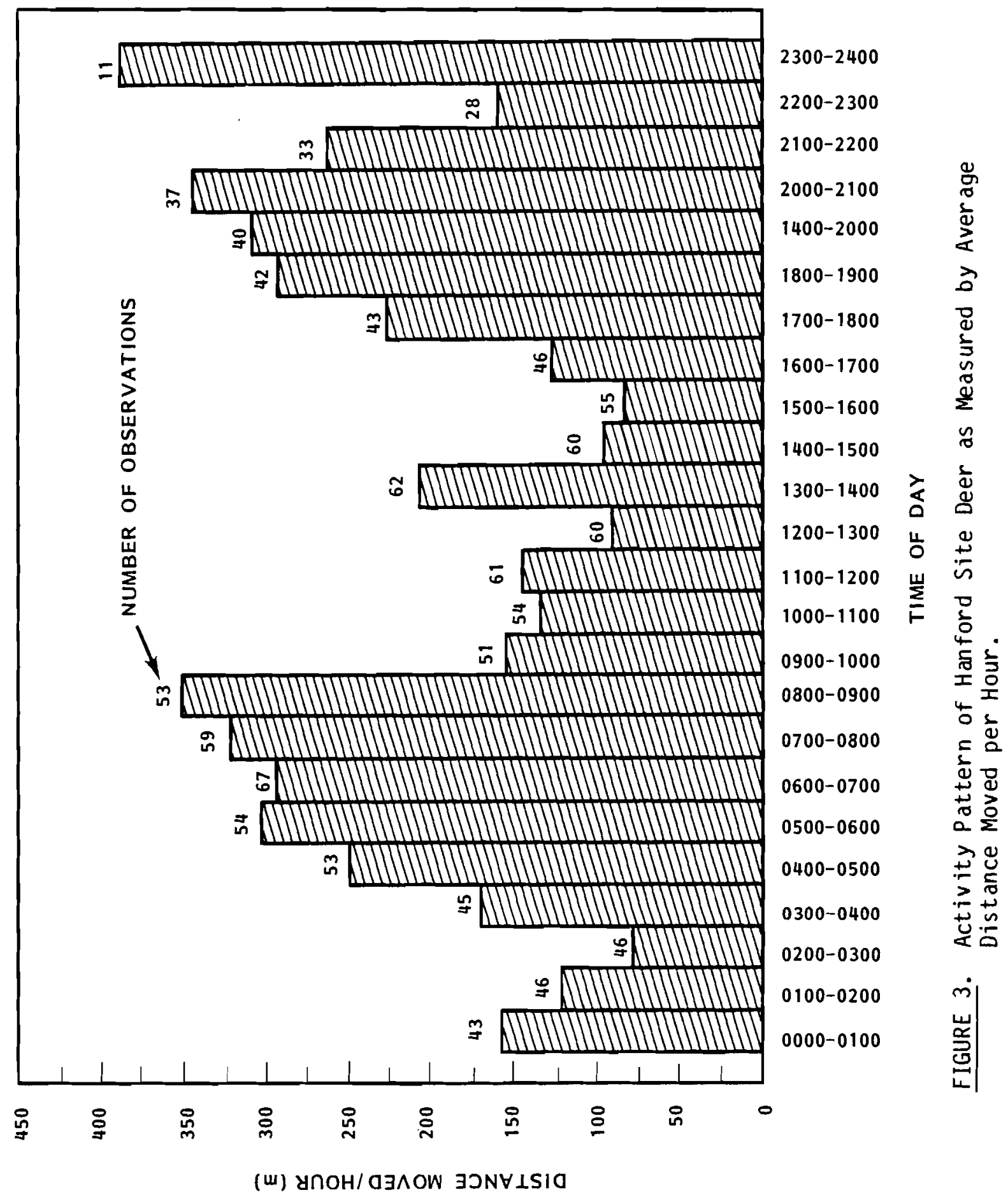




\section{HERD HEALTH}

Based on information obtained from the radio-collared deer and deer sampled for radionuclides, several aspects of herd health were monitored, including: mortality, age structure, reproduction, and disease incidence.

Mortality Estimates

The 37 radio-collared deer were monitored a total of 297 deer-months (24.75 deer-years). During this period two animals (Nos. 890 and 567) died. Deer No. 890 was harvested legally by a hunter on the Rattlesnake Mountain Wildlife Recreation Area adjacent to and southwest of the Hanford Site in October, 1981, approximately five months after moving away from the 200 Area. Deer No. 567 was killed illegally along the Hanford Site shoreline near the Washington Public Power Supply System facility sometime in September-October, 1981, approximately four to five months after dispersing from the 200 Area. Based on this small sample size, the probability of a deer being legally or illegally harvested during a year is 0.08 ; the $95 \%$ confidence interval is 0 to 0.21 per year. In other words, $8 \%$ of the Hanford deer herd may be harvested each year; however, this estimate is based on a small sample size and should be interpreted carefully. There were no other mortalities (vechile killed, predation, disease, etc.) observed during the study.

Age and Reproduction

Based on tooth wear (Taber 1969), four of the 17 (24\%) deer collected for radionuclide analys is were older than 10.5 years. This percentage of old animals appears to be considerably greater than that observed for other mule deer herds in Washington where from 2 to $9 \%$ of hunter-killed female deer were older than 10.5 years (Zeigler 1978, pg. 56) and in Colorado where from 9 to $11 \%$ of hunter-killed female deer were older than 9.3 years (Medin and Anderson 1979, pg. 22). Small sample sizes and capture techniques may have biased our estimate of age structure; however, because the Hanford deer herd is lightly harvested, one would expect a large number of old-age animals.

Eleven female deer were collected during their gestation period, 10 of which were examined for pregnancy. All 10 individuals ( $>1.5$ years old) were pregnant, eight with two prenatal young and two with one prenatal young. 
Overall fetal rate was 1.80 , which is similar to that observed for relatively productive herds (Zwank 1976). Eberhardt, Hedlund, and Rickard (1979) observed an apparent decrease in fawn production for deer residing along the Columbia River shoreline of the Hanford Site. It was unknown whether this was related to fewer female adult deer present, a drop in actual production of young, or postnatal mortality. Data from the present study indicate that the observed drop in fawn production was probably not related to reproductive success (from conception to birth) of individual deer.

Disease

Blood from some captured deer was tested for the presence of antibodies for several disease including: anaplasmosis ( $N=10$ deer examined), brucellosis $(N=10)$, leptospirosis $(N=10)$, infectious bovine rhinotracheitis $(N=$ 10), parainfluenza type $3(N=10)$, and the blue tongue-epizootic hemorrhagic disease complex $(N=13)$. Antibodies were detected only for the blue tongueepizootic hemorrhagic disease (BT-EHD) complex ( $N=12$ of 13 samples examined), indicating only that these animals had been exposed to the disease sometime in the past. No blue tongue viral isolates were obtained in six animals examined. BT-EHD is generally fatal in mule deer when actually contracted (Lance 1981).

\section{RADIOLOGICAL CONSIDERATIONS}

Twelve radio-collared deer from the 200 East Area waste management operations sites that met or exceeded the 70-d minimum residency requirement for ${ }^{137} \mathrm{Cs}$ body burdens and five control deer inhabiting areas remote from waste management activities were sacrificed.

Radionuclide Concentration in Radio-Collared Deer

Gamma spectral analysis of muscle and liver samples identified only ${ }^{137} \mathrm{Cs}$ above anticipated background levels (Table 2). Strontium-90 was detected in bone samples (Table 2).

The concentration of any ingested radionuclide in animal tissue depends on several biological and physical factors. These factors include: the concentration of radionuclide in the ingested (food) material, the amount of 
TABLE 2. Concentrations of ${ }^{137} \mathrm{Cs}$ and $90 \mathrm{Sr}$ in Mule Deer Muscle and Bone, Respecitively, from 17 Radio-Collared Animals Collected on the Hanford Site

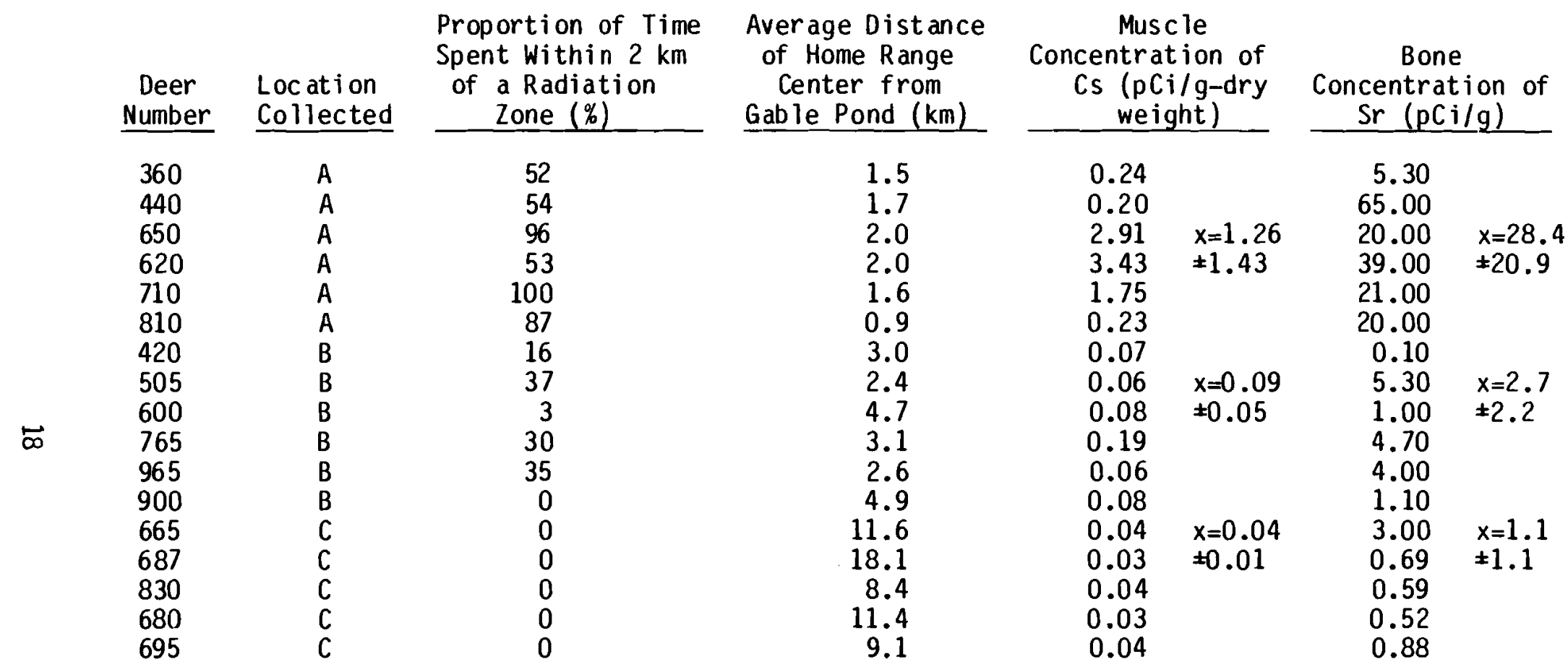

(a) $A=$ deer spending $>50 \%$ of their time with in $2 \mathrm{~km}$ of radiation 20 enes; $B=$ deer residing near 200 Area but spending $<50 \%$ of their time within $2 \mathrm{~km}$ of radiation zones; $\mathrm{C}=$ control deer residing away from the 200 Area.

(b) Home range center is average of all $x y$ coordinates for each individual deer. Point on Gable Pond corresponds to area of highest ${ }^{137} \mathrm{Cs}$ gamma exposure rate (Tipton, 1974). 
material ingested, the fraction of ingested radionuclide assimilated, the biological retention half-time, and the physical half-life of the radionuclide. Free ranging animals, such as deer, move about in their foraging activity and use their home ranges in a nonuniform pattern. Thus, heterogeneity of contaminant level in the environment may result in different concentrations of radionuclides in an individual with time and a variation in concentration from animal to animal depending on individual feeding preferences or habits. If free ranging animals alternate among foods having different levels of contamination, then the contaminant concentration in their tissues may vary consider$a b l y$ depending on the length of time they feed at each contaminant level and the time lapsed since they shifted from one food source to the other.

The data in Table 2 show uniform concentrations [coefficient of variation $(\mathrm{CV})=0.15$ and 0.55$]$ of ${ }^{137} \mathrm{Cs}$ in the muscle and liver, respectively, for the control deer. This suggests a uniform concentration in the environment such as might occur from widely distributed (i.e. fallout) radionuclides. The 200 Area, however, show considerable variation of ${ }^{137} \mathrm{Cs}$ in muscle and liver, with CV's of 1.57 and 2.16, respectively. Although we do not know the exact location or source (forage type, drinking water, or soil) of ingested ${ }^{137} \mathrm{Cs}$, it appears to be localized and nonuniformly distributed in the animal's home $r$ ange.

The ${ }^{90} \mathrm{Sr}$ data $(\mathrm{CV}=0.92)$ for the control deer was more variable than the ${ }^{137} \mathrm{Cs}$ information. This was mainly due to one animal (Deer No. 665, Table 2) that had $3 \mathrm{pCi} / \mathrm{g}$ (dry) bone concentration compared to values ranging from 0.52 to $0.88 \mathrm{pCi} / \mathrm{g}$ for the remaining four samples. This animal was either exposed to a local source of ${ }^{90} \mathrm{Sr}$, or moved from such a location (200 Area for example) at some time prior to radio-tagging, but within less than five biological half-times for ${ }^{90} \mathrm{Sr}$ elimination. The criteria for including individual animals in the samples for both the waste management vicinity and the control site was based on the biological half-time for ${ }^{137} \mathrm{Cs}$ ( -14 days) and not ${ }^{90} \mathrm{Sr}$ ( 170 days). Thus any animal having left a contaminated site for more than 10 weeks ( 5 half-times of ${ }^{137} \mathrm{Cs}$ ) but less than 120 weeks ( 5 half-times for 
${ }^{90} \mathrm{Sr}$ ) could be at environmental equilibrium for fallout ${ }^{137} \mathrm{Cs}$, which this particular deer was, and yet show residual ${ }^{90} \mathrm{Sr}$ concentrations in bone from the previous area visited.

Two sample t-tests (assuming unequal variances) for differences between the lognormal transformations of the ${ }^{137} \mathrm{Cs}$ and ${ }^{90} \mathrm{Sr}$ concentrations between the 12 deer from near the 200 Area and the 5 control deer that inhabited areas from 7 to $17 \mathrm{~km}$ away revealed significant $(p<0.05)$ differences and suggested that the 200 Area deer do contain ${ }^{137} \mathrm{Cs}$ and ${ }^{90} \mathrm{Sr}$ in excess of that contributed by fallout sources.

Two methods were used to further examine radionuclide concentrations in Hanford deer. These included a comparison of ${ }^{137} \mathrm{Cs}$ and ${ }^{90} \mathrm{Sr}$ tissue data with: 1) the proportion of time marked deer spent in or near the radiation zones associated with Gable and B Ponds, and 2) the average distance sampled deer resided away from Gable Pond. Since radio-collared deer were detected only infrequently within radiation zones and because the error associated with relocating radio-collared deer often precluded detection within a narrow radiation zone, the proportion of time spent within 1 and $2 \mathrm{~km}$ of the zones was calculated for a comparison with tissue contaminant data (Table 2). In addition, the distance from the center of each deer's home range (as calculated by averaging all XY coordinates for that animal) to Gable Pond (Table 2) was compared with tissue contaminant data. Gable Pond was selected because radio-collared deer spent considerably more time near Gable Pond than near B Pond.

A positive, significant $(p<0.01)$ correlation was obtained between the proportion of time deer spent near radiation zones and concentrations of radionuclides in their tissues. The relationship was also significant $(p<0.01)$ and positive when the reciprocal of the distance deer resided from Gable Pond and radionuclide concentrations were compared. The reciprocal of distance was used as a transformation to obtain a more nearly linear relationship. A comparison of the correlation coefficients (Snedecor and Cochran 1980, pg. 186-187) in Table 3 revealed that they were not significantly ( $p>0.05$ ) different from one another, that is, the proportion of time deer spent near radiation zones was not a better predictor of contaminant levels than was distance of a deer's home range from Gable Pond. 
TABLE 3. Correlation $\left(r^{2}\right)$ of Radionuclides in Deer Tissue With Proportions of Time Deer Spent Near Radiation Zones and With Distances Deer Resided from Gable Pond.

\begin{tabular}{|c|c|c|c|}
\hline & $\begin{array}{l}\text { Normal } \mathrm{Log} \\
\text { of } 137 \mathrm{Cs} \\
\text { in Muscle }\end{array}$ & $\begin{array}{l}\text { Normal } \log \\
\text { of } 137 \mathrm{Cs} \\
\text { in Liver }\end{array}$ & $\begin{array}{l}\text { Normal Log } \\
\text { of } 90 \mathrm{Sr} \\
\text { in Bone }\end{array}$ \\
\hline $\begin{array}{l}\text { Proportion of time deer } \\
\text { spent with in } 1 \mathrm{~km} \text { of } \\
\text { radiation zone }\end{array}$ & 0.54 & 0.47 & 0.34 \\
\hline $\begin{array}{l}\text { Proportion of time deer } \\
\text { spent with in } 2 \mathrm{~km} \text { of } \\
\text { radiation zone }\end{array}$ & 0.69 & 0.53 & 0.63 \\
\hline $\begin{array}{l}\text { Reciprocal of distance } \\
\text { from center of deer's } \\
\text { home range to Gable } \\
\text { Pond }\end{array}$ & 0.36 & 0.18 & 0.48 \\
\hline
\end{tabular}

Based on the proportion of time deer spent within $2 \mathrm{~km}$ of radiation zones, there were three basic groups of deer: 1) 200 Area deer spending greater than $50 \%$ of their time near radiation zones (Group "A"); 2) 200 Area deer spending less than $50 \%$ of their time near radiation zones (Group "B"); and 3) non-200 Area deer that did not visit the vicinity of radiation zones with in 70-d prior to collection (Group "C"). A comparison between the log normal transformed radionuclide data for the three groups of deer using Scheffe's Test (Snedecor and Cochran 1980, pg. 232) showed that the radionuclide content in each of the various tissues was significantly different $(p<0.05)$ for all intercomparisons between the three groups except for the comparison of ${ }^{137} \mathrm{Cs}$ in the livers of "B" and "C" Group animals ( $p>0.05$ ). Therefore, 200 Area deer spending greater than $50 \%$ of their time near the Gable and $B$ Pond radiation zones had statistically higher radiocontaminant levels than did 200 Area deer spending less than $50 \%$ of their time near radiation zones. This indicates that, at least for the deer we studied, the major source(s) of ${ }^{137} \mathrm{Cs}$ and ${ }^{90} \mathrm{Sr}$ available to deer were near the radiation zones. However, we did not examine deer from a 11 vicinities of the 200 Area and there may be other contaminant sources available to deer. 
Comparisons With Other Studies

Table 4 provides a historical summary of ${ }^{137} \mathrm{C}$ s data from Hanford deer muscle samples. Comparisons of our data with the results from previous samplings is difficult. Site conditions have changed through the more than three decades during which samples were collected. For example, during the period of 1958-1969 atmospheric weapons testing that contributed to world-wide fallout was most active. In addition, Hanford Site fuel reprocessing was occurring and several once-through cooled production reactors were operating. All of these activities declined during the 1960's and early 1970's. Also, the bas is for deer sampling has changed.

Much of the early sampling (1958-1969) was prompted by a desire to obtain information on fallout radionuclide concentrations in deer; whereas, the routine monitoring of the 1970's at Hanford was conducted to monitor ambient radionuclide concentrations in deer. Our study emphasized deer residing near the environmental radiation zones in the 200 Area. The average concentration of ${ }^{137} \mathrm{Cs}(0.8 \pm 1.2 \mathrm{pCi} / \mathrm{g}$-dry) observed in deer muscle during our study is based on a high proportion of animals (12 of 17) intentionally collected from waste management environs. Thus, the "average" is heavily weighted with individuals having a greater probability of being above background ${ }^{137} \mathrm{Cs}$ concentrations. The observed concentration is therefore not representative of all Hanford Site deer, whereas the earlier samplings may have been.

We bel ieve that the maximum concentrations (Table 4) are more representative of ${ }^{137} \mathrm{Cs}$ of Hanford origin while the average values more accurately reflect changes in fallout concentrations. Improved waste management practices implemented over the past 30 years combined with a decline in waste operation and reprocessing activity probably accounts for the more than 10-fold reduction in maximum observed ${ }^{137} \mathrm{Cs}$ muscle concentrations in deer. The decrease in the average values may reflect the diminished availability of fallout ${ }^{137} \mathrm{Cs}$.

The $1981-82{ }^{137} \mathrm{Cs}$ concentrations in muscle tissue from radio-collared deer were compared with routine environmental monitoring samples collected from six road-kil led animals during 1981. Inspection of the monitoring data revealed that there was a single sample with a "high" concentration 
TABLE 4. Cesium-137 Concentrations in Muscle of Mule Deer from the Hanford Site

\begin{tabular}{|c|c|c|c|c|}
\hline $\begin{array}{l}\text { Time } \\
\text { Period }\end{array}$ & Study & $\begin{array}{l}\text { Number of } \\
\text { Deer Sampled }\end{array}$ & $\begin{array}{r}{ }^{137} \mathrm{Cs} \text { Conc } \\
\text { (pCi/g-dry } \\
\text { Average }\end{array}$ & $\begin{array}{l}\text { tration } \\
\frac{\text { ight } \pm 150)}{\text { Maximum }}\end{array}$ \\
\hline $1958-1969$ & Fallout & 85 & $1.9 \pm 6.3$ & 51.3 \\
\hline $1971-1980$ & Routine Monitoring & 35 & $0.3 \pm 0.9$ & 17.4 \\
\hline 1981 & Routine Monitoring & 6 & $0.3 \pm 0.7$ & 1.8 \\
\hline $1981-1982$ & Present Study & 17 & $0.8 \pm 0.7$ & 3.4 \\
\hline
\end{tabular}

(1.8 $\mathrm{pCi} / \mathrm{g}-d r y)$ and that the remaining five had an average $(0.07 \mathrm{pCi} / \mathrm{g}-d r y)$ similar to that of our control group $(0.04 \mathrm{pCi} / \mathrm{g}-d r y)$. Thus, it appears that the maximum ${ }^{137} \mathrm{Cs}$ concentration observed in our study for Hanford deer ( $3.4 \mathrm{pCi} / \mathrm{g}$-dry) is comparable with the maximum concentration observed in the Hanford Site routine monitoring ( $1.8 \mathrm{pCi} / \mathrm{g}-\mathrm{dry})$. The "high" value observed during routine monitoring was from a deer killed near the 200 East Area, and it is possible that this animal was a resident of the waste management environs.

Monitoring data from other DOE sites for ${ }^{137} \mathrm{CS}$ in deer muscle showed that several hundred Savannah River $P$ lant deer had average concentrations of 32 and $40 \mathrm{pCi} / \mathrm{g}$ (corrected to dry weight) for 1980 and 1981, respectively, (duPont Company, 1982). Muscle from 37 Oak $R$ idge deer were reported to average $0.67 \pm 0.88 \mathrm{pCi} / \mathrm{g}$-dry for 1981 (Union Carbide Company, 1982). Thus our value is within the range of average concentrations reported for Savannah River Plant and Oak Ridge National Laboratory.

Radionuclide Transport Potential by Hanford Deer

Lands with in the Hanford Site boundary are closed to public hunting. The lack of a legal harvest, coupled with the expanse of the Hanford Site $\left(1,476 \mathrm{~km}^{2}\right)$, which helps isolate animals in the interior of the Site, and the security patrols, which minimize trespass, should contribute to a small probability of harvest for Hanford deer. The age distribution data (see Herd Health section) suggest that this is the case. There seems to be a high 
percentage of old deer among the 17 animals sampled for this study, suggesting little annual turnover, which indicates low harvest by man.

We do not have the kinds of data necessary to estimate the numbers of Hanford deer that may be harvested in any one year. That would require estimates of both the numbers of deer present and the legal and illegal harvest. Our data do indicate that a sizable proportion of deer that spend at least some time in the 200 areas move to locations of potential harvest. Eight of 21 (38\%) deer captured and radio-collared in the 200 Area vicinity made movements to areas where they had increased probability of being harvested and two of then were killed by hunters. Four of those deer moved to offsite locations and four moved to the riparian zone along the Columbia River.

The two 200 Area deer that were harvested moved away from the 200 Area four to five months prior to being killed. Thus, essentially $99.7 \%$ of the ${ }^{137} \mathrm{Cs}$ that may have been in their muscle as a result of occupying the 200 Area, would have been biologically eliminated before the animals were killed. of the eight 200 Area deer making movements to areas of potential harvest, five moved more than three months prior to the legal hunting season. Thus those deer, if harvested during the regular legal 0ctober hunting season, would have little potential for injestion by man of ${ }^{137} \mathrm{Cs}$ originating from the 200 Area. Monitoring Implications

Variation in radionuclide concentration data and the general level of mobility displayed by the Hanford deer herd have implications for radiological monitoring. The radiological concentration data shows ranges of 2 to 3 orders of magnitude for ${ }^{137} \mathrm{Cs}$ and ${ }^{90} \mathrm{Sr}$ in muscle and bone, respectively (Table 2). Day-to-day movements of several kilometers within individual animal's home range $\left(39 \mathrm{~km}^{2}\right.$ ) were observed as well as dispersal movements (one-way) of up to $25 \mathrm{~km}$ and trips (round trip movements of short duration) of up to $20 \mathrm{~km}$. Previous fawn tagging studies (Eberhardt, Hedlund, Rickard 1979) have shown movements up to $113 \mathrm{~km}$. A collection of samples from several deer by random or opportunistic methods (such as "road kill" sampling) may show "high" or "low" concentrations, within the 2-3 order of magnitude range, depending on the recent site residence history of deer in the sample. Thus year-to-year sample 
variations will reflect chance occurrence of the various population cohorts in the sample. Trend analysis of general radionuclide concentration in deer on a year-to-year basis would be impractical and the determination of sizable changes in radionuclide concentrations (say by a factor of 10 ) would not be possible.

Data obtained during our study demonstrate that Hanford mule deer residing near the 200 Area waste management ponds, Gable Pond and B Pond, have elevated ${ }^{137} \mathrm{Cs}$ and ${ }^{90} \mathrm{Sr}$ concentrations in their tissues relative to deer living in Hanford Site areas remote from waste management zones. However, the radionuclide concentrations we observed in Hanford deer are low and appear to have decreased from levels observed in Hanford deer during the 1960's and 1970's. 


\section{REFERENCES}

Beasom, S. L., W. Evans, and L. Temp 1e. 1980. The Drive Net for Capturing Western Big Game. J. Wildl. Manage. 44(2):478-483.

Burt, W. H. 1943. "Territoriality and Home Range Concepts as Applied to Mamma is." J. of Mamma 1. 24:346-352.

Cadwe 11, L. L., R. G. Schreckhise, and R. E. Fitzner. 1979. Cesium-137 in Coots Fulica americana on Hanford Waste Ponds: Contribution to Population Dose and Offsite Transport Estimates. PNL-SA-7167, Pacific Northwest Laboratory, Richland, Washington.

Cushing, C. E., and D. G. Watson. 1974. Aquatic Studies of Gable Mountain Pond. BNWL-1884, Pacific Northwest Laboratory, Richland, Washington.

Dasmann, R. F., and R. D. Taber. 1956. "Behavior of Columbian Black-Tailed Deer with Reference to Population Ecology." J. of Mammal. 37(2):143-164.

Daubenmire, R. 1970. "Steppe Vegetation of Washington." Wash. Agric. Exp. Stn. Tech. Bu11. 62. Washington State University, Pullman, Washington.

Davis, J. J., and R. F. Foster. 1958. Bioaccumulation of Radioi sotopes Through Aquatic Food Chains. Ecology 39(3):530-535.

Drolet, C. A. 1976. "Distribution and Movements of White-Tailed Deer in Southern New Brunswick in Relation to Environmental Factors." Can. Field-Nat. 90(2):123-136.

Eberhardt, L. E., J. D. Hed lund, and W. H. Rickard. 1979. Tagging Studies of Mule Deer Fawns on the Hanford Site, 1969-1977. PNL-3147, Pacific Northwest Laboratory, Richland, Washington.

Eberhardt, L. E., and G. C. White. 1979. Movements of Mule Deer on the Los A lamos National Environmental Research Park. LA-7742, Los Alamos National Laboratory, Los Alamos, New Mexico.

Eberhardt, L. L., et al. 1969. "A Study of Fallout Cesium-137 in the Pacific Northwest." J. of Wildl. Manage. 33(1):103-112.

E. I. du Pont de Mours \& Company, Inc. 1982. Environmental Monitoring in the Vicinity of the Savannah River Plant. Annual Report for 1981. DPSPU 82-30-1. E. I. du Pont de Mours \& Company, Inc., Aiken, South Carolina.

Geist, V. 1981. "Behavior: Adaptive Strategies in Mule Deer." In: Mule and Black-Tailed Deer of North America, ed. 0. C. Wallmo, pp. 157-223. University of Nebraska Press, Lincoln. 
Hakonson, T. E., and F. W. Wicker. 1969. "Uptake and Elimination of ${ }^{134} \mathrm{Cs}$ by Mule Deer." In: Symposium and Radioecology, eds. D. J. Nelson and F. C. Evans, pp. 616-622. CONF-670503. U.S. Atomic Energy Commission, Division of Technical Information Extension, Oak Ridge, Tennessee.

Hed lund, J. D. 1975. "Tagging Mule Deer Fawns in South-Central Washington, 1969-1974." Northwest Sci. 49(3):153-157.

Inglis, J. M., et al. 1979. "Home Range of White-Tailed Deer in Texas Coastal Prairie Brushland." J. Mammal. 60(2):377-389.

Jennrich; R. I., and F. B. Turner. 1969. "Measurement of Non-circular Home Range." Theoret. Biol. 22:227-237.

Kammermeyer, K. E., and R. L. Marchinton. 1977. "Seasonal Change in Circadian Activity of Radio-Monitored Deer." J. Wildl. Manage. 41(2):315-317.

Lance, W. R. 1981. "Bluetongue-Epizootic Hemorrhagic Disease Complex." In: Manual of Common Wildlife Diseases in Colorado, ed. W. J. Adrian, pp. 31-34. Colorado Division of Wildlife, Fort Collins.

Linsdale, J. M., and P. Q. Tomich. 1953. A Herd of Mule Deer. University of California Press, Berkeley.

MacDonald, D. W., F. G. Ball, and N. G. Hough. 1980. "The Evaluation of Home Range Size and Configuration Using Radio Tracking Data." In: A Handbook of Biotelametry and Radio Tracking, ed s. C. J. Amlaner and D. W. MacDonald, pp. 405-424. Pergamon Press, 0xford.

Markham, 0. D., et al. 1982. "Radionuclides in Pronghorn Resulting from Nuc lear Fuel Reprocessing and Worldwide Fallout." J. Wildl. Manage. $\underline{46}(1): 30-42$.

Medin, D. E., and A. E. Anderson. 1979. "Modeling the Dynamics of a Colorado Mule Deer Population." Wildl. Manage. Monograph No. 68.

Miller, F. L. 1970. "Distribution Patterns of Black-Tailed Deer (Odocoileus hemionus columbianus) in Relation to Environment." J. Mammal. $51(2): 248-260$.

National Academy of Sciences. 1978. Radioactive Wastes at the Hanford Reservation - A Technical Review. National Academy of Sciences, Washington, D.C.

Odum, E. P., and E. J. Kuenzler. 1955. "The Measurement of Territory and Home Range Size in Birds." Auk. 72:128-137.

Rickard, W. H., R. E. Fitzner, and C. E. Cushing. 1981. "Biological Colonization of an Industrial Pond: Status After Two Decades." Envir. Conserv. 8: $241-247$. 
Robinette, W. L. 1966. "Mule Deer Home Range and Dispersal in Utah." J. Wildl. Manage. $30(2): 335-349$.

Rongstad, 0. J., and J. R. Tester. 1969. "Movements and Habitat Use of WhiteTailed Deer in Minnesota." J. Wildl. Manage. 33(2):366-379.

Short, H. L. 1981. "Nutrition and Metabolism." In: Mule and Black-Tailed Deer of North America, ed. 0. C. Wallmo, pp. 99-127. University of Nebraska Press, Lincoln.

Siniff, D. B. 1966. "Computer Programs for Analyzing Radio Tracking Data." Minnesota Museum of Nat. Hist. Tech. Rep. No. 12. University of Minnesota, Minneapolis.

Siniff, D. B., and J. R. Tester. 1965. "Computer Analysis of Animal Movement Data Obtained by Telemetry." Bio. Sci. 15:104-108.

Snedecor, G. W., and W. G. Cochran. 1980. Statistical Methods. The Iowa State University Press, Ames.

Sparrowe, R. D., and P. F. Springer. 1970. "Seasonal Activity Patterns of White-Tailed Deer in Eastern South Dakota." J.Wildl. Manage. 34(2):420-431.

Steigers, W. D., Jr. 1978. Mortality of Mule Deer Fawns in South-Central Washington. M. S. Thes is, Brigham Young University, Provo, Utah.

Sula, M. J., et al. 1982. Environmental Surveillance at Hanford for CY-1981. PNL-4211. Pacific Northwest Laboratory, Richland, Washington.

Taber, R. D. 1969. "Criteria of Sex and Age." In: Wildiife Management Techniques. 3rd ed. Ed. R. H. Giles, Jr., pp. 325-402.

Thorp, J. M., and W. T. Hinds. 1977. Microclimates of the Arid Lands Ecology Reserve, 1968-1975. BNWL-SA-6231. Pacific Northwest Laboratory, Richland, Washington.

Union Carbide Company. 1982. Environmental Monitoring Report. United States Department of Energy, Oak Ridge Facilities - Calendar Year 1981. Y/CIB-16. Union Carbide Company, Oak Ridge, Tennessee.

Uresk, D. W., and V. A. Uresk. 1980. Diets and Habitat Analys is of Mule Deer on the 200 Areas of the Hanford Site in Southcentral Washigton. PNL-2461. Pacific Northwest Laboratory, Richland, Washington.

U.S. Testing, Inc. 1980. Procedure Manual. UST-RL-PM-9-80, U.S. Testing, Inc., Richland, Washington.

Zalunardo, R. A. 1965. "The Seasonal Distribution of a Migratory Mule Deer Herd." J. Wildl. Manage. 29:345-351. 
Zeigler, D. L. 1978. "The Okanogan Mule Deer Herd." Washington Dept. Game Biol. Bul1. No. 15. Washington State Printing Plant, OTympia.

Zwank, P. J. 1976. "Mule Deer Productivity--Past and Present." In: Mule Deer Decline in the West: A Symposium, eds. G. W. Workman and J. B. Low, pp. 79-86. Utah State University, Logan, Utah. 
APPENDIX A

HOME RANGE SIZE ESTIMATES FOR ALL RADIO-COLLARED

MULE DEER MONITORED ON THE HANF ORD SITE 


\begin{tabular}{|c|c|c|c|c|c|c|}
\hline \multirow[b]{2}{*}{$\begin{array}{c}\text { Deer } \\
\text { Number }\end{array}$} & \multirow[b]{2}{*}{$\underline{\text { Sex }}$} & \multirow{2}{*}{$\begin{array}{l}\text { Number } \\
\text { of } \\
\text { Fixes } \\
\end{array}$} & \multirow{2}{*}{$\begin{array}{l}\text { Number of } \\
\text { Months } \\
\text { Monitored }\end{array}$} & \multicolumn{3}{|c|}{ Home Range Size, $\mathrm{km}^{2}$} \\
\hline & & & & $\begin{array}{l}\text { Minimum Convex } \\
\text { Polygon Estimate } \\
\end{array}$ & $\begin{array}{c}95 \text { Ellipse } \\
\text { Estimate } \\
\end{array}$ & $\begin{array}{l}\text { Grid Square } \\
\text { Est imate } \\
\end{array}$ \\
\hline 360 & $\mathrm{~F}$ & 25 & 3 & 10.6 & 23.0 & $4.4^{(a)}$ \\
\hline 420 & $\mathrm{~F}$ & 31 & 3 & 9.2 & 15.0 & $3.6^{(a)}$ \\
\hline 440 & $\mathrm{~F}$ & 24 & 2 & 9.0 & 20.3 & $3.6^{(a)}$ \\
\hline 505 & $\mathrm{~F}$ & 30 & 3 & 9.1 & 14.6 & $4.0^{(a)}$ \\
\hline 515 & $\mathrm{~F}$ & 81 & 15 & 36.7 & 6.0 & $31.0^{(b)}$ \\
\hline 530 & $\mathrm{~F}$ & 150 & 17 & 93.3 & 83.4 & $17.8^{(b)}$ \\
\hline 540 & $F$ & 46 & 4 & 52.4 & 83.5 & $6.8^{(a)}$ \\
\hline 545 & $F$ & 68 & 11 & 53.3 & 51.0 & $29.0^{(b)}$ \\
\hline 575 & $\mathbf{F}$ & 28 & 4 & 10.3 & 18.7 & $13.0^{(\mathrm{b})}$ \\
\hline 590 & M & 56 & 11 & 36.7 & 65.5 & $34.0^{(b)}$ \\
\hline 600 & M & 31 & 2 & 18.2 & 30.7 & $5.2^{(a)}$ \\
\hline 605 & $\mathbf{F}$ & 79 & 7 & 18.5 & 29.8 & $9.0^{(a)}$ \\
\hline 620 & $F$ & 74 & 7 & 30.9 & 40.1 & $10.4^{(a)}$ \\
\hline 627 & M & 56 & 11 & 64.2 & 80.6 & $29.0^{(\mathrm{b})}$ \\
\hline 665 & $\mathbf{F}$ & 90 & 15 & 4.3 & 4.0 & $10.0^{(\mathrm{b})}$ \\
\hline 680 & M & 73 & 12 & 30.6 & 24.2 & $22.0^{(\mathrm{b})}$ \\
\hline 687 & $F$ & 46 & 9 & 16.2 & 21.6 & $17.0^{(\mathrm{b})}$ \\
\hline 695 & $F$ & 88 & 148 & 23.8 & 28.9 & $25.0^{(\mathrm{b})}$ \\
\hline 710 & $\mathrm{~F}$ & 37 & 4 & 16.9 & 23.5 & $5.4^{(a)}$ \\
\hline 725 & $F$ & 64 & 14 & 30.4 & 33.9 & $24.0^{(\mathrm{b})}$ \\
\hline 755 & $\mathrm{~F}$ & 81 & 17 & 15.1 & 17.5 & $18.0^{(\mathrm{b})}$ \\
\hline 765 & $F$ & 33 & 3 & 9.1 & 13.1 & $4.8^{(a)}$ \\
\hline 770 & $F$ & 42 & 9 & 17.5 & 32.6 & $20.0^{(\mathrm{b})}$ \\
\hline 800 & & 50 & 11 & 48.9 & 53.8 & $27.0^{(\mathrm{b})}$ \\
\hline 810 & $F$ & 31 & 3 & 22.1 & 39.8 & $4.8^{(a)}$ \\
\hline 815 & $F$ & 45 & 9 & 40.2 & 84.5 & $19.0^{(b)}$ \\
\hline 830 & $F$ & 48 & 10 & 39.3 & 71 & $8.0^{(a)}$ \\
\hline 845 & $F$ & 53 & 11 & 25.6 & 27.4 & $16.0^{(b)}$ \\
\hline 860 & $F$ & 40 & & & .1 & $6.6^{(\mathrm{a})}$ \\
\hline 875 & $F$ & 50 & 12 & 22.3 & 22.3 & $18.0^{(b)}$ \\
\hline 885 & $\mathrm{~F}$ & 47 & 4 & 51.1 & 81.0 & $7.0^{(\mathrm{a})}$ \\
\hline 900 & $F$ & 32 & 3 & 11.2 & 18.8 & $4.6^{(a)}$ \\
\hline 920 & M & 49 & 11 & 83.2 & 71.3 & $22.0^{(\mathrm{b})}$ \\
\hline 965 & $F$ & 34 & 3 & 9.9 & 15.6 & $4.6^{(a)}$ \\
\hline
\end{tabular}

(a) Based on grid square size of $447 \mathrm{~m} \times 447 \mathrm{~m}$.

(b) Based on grid square size of $1000 \mathrm{~m} \times 1000 \mathrm{~m}$. 
APPENDIX B

COMPARISON OF HOME RANGE ESTIMATION TECHNIQUES 
APPENDIX B

\section{COMPARISON OF HOME RANGE ESTIMATION TECHNIQUES}

A number of both natural (e.g. topography, season, availability of food, breeding activity, population density, cover density) and computational (e.g. number of relocations, length of study) factors affect home range size estimates (Robinette 1966; Macdonald, Ball, and Hough 1980). Home range size estimates obtained by the minimum convex polygon and grid square methods $c$ an be influenced by the number of relocations made on an individual, while estimates obtained by the $95 \%$ elliptical technique are less affected by sample size (Macdonald, Ball, and Hough 1980). Data collected during this study also demonstrate the influence of the number of relocations and, correspondingly, the length of study on home range sizes obtained by the various estimators. A comparison of home range estimates obtained by the three techniques for four deer that were consistantly together, but were radio-tracked for different lengths of time, shows little variation in home range size estimates obtained by the elliptical technique but considerable variability in results obtained by the minimum convex polygon and grid square methods of analysis (Table B-1). Since the number of relocations per individual varied considerably during our study, comparisons of home range size between individuals or groups of animals are based on the elliptical technique.

TABLE B-1. Comparison of Home Range Sizes Obtained by Three Estimation Techniques for Four Closely Associated Hanford Site Deer.

\begin{tabular}{|c|c|c|c|c|c|}
\hline \multirow[b]{2}{*}{$\begin{array}{l}\text { Deer } \\
\text { Number }\end{array}$} & \multirow{2}{*}{$\begin{array}{c}\begin{array}{c}\text { Number } \\
\text { of } \\
\text { Reloc ations }\end{array} \\
\end{array}$} & \multirow{2}{*}{$\begin{array}{l}\text { Number of } \\
\text { Months } \\
\text { Followed }\end{array}$} & \multicolumn{3}{|c|}{ Home Range Size, $\mathrm{km}^{2}$} \\
\hline & & & $\begin{array}{l}\text { Minimum Convex } \\
\text { Polygon Estimate }\end{array}$ & $\begin{array}{l}95 \% \text { Ellipse } \\
\text { Estimate } \\
\end{array}$ & $\begin{array}{c}\text { Grid Square } \\
\text { Estimate } \\
\end{array}$ \\
\hline $\begin{array}{l}530 \\
540 \\
860 \\
885\end{array}$ & $\begin{array}{r}150 \\
46 \\
40 \\
47\end{array}$ & $\begin{array}{r}17 \\
4 \\
4 \\
4\end{array}$ & $\begin{array}{l}93 \\
52 \\
53 \\
51\end{array}$ & $\begin{array}{l}83 \\
84 \\
89 \\
81\end{array}$ & $\begin{array}{r}18 \\
7 \\
7 \\
7\end{array}$ \\
\hline
\end{tabular}




\section{DISTRIBUTION}

No. of

Copies

OFFSITE

27 DOE Technical Information Center

2 Ecological Research Division Office of Health a Environmental Research

U.S. Department of Energy

Washington, D.C. 20545

ATTN: W. S. Osburn

R. L. Watters

S. I. Auerbach

Oak Ridge National Laboratory

P.0. Box $X$

Oak Ridge, TN 37830

B. Bi swe 11

958 Sunset $B$ lvd. NE $\alpha B$

Renton, WA 98056

T. A. Clausing

Washington Department of Game

Rt. 2, Box 2710

Kennewick, WA 99336

D. N. Flohr

Washington Department of Game

193 Bitterroot Dr.

Richland, WA 99352

R. A. Garrott

Little Hills Wildlife Area

3284 RBC 22

Meeker, CO 81641

T. E. Hakonson

Group LS-6

Los Alamos National Laboratory

P.0. Box 1663

Los Alamos, NM 87545
No. of

Copies

0. D. Markham

Radiological and Environmental Sciences Laboratory

P.0. Box 2108

Idaho Falls, ID 83401

J. McIntosh

Washington Department of Game

420 W. 31 st Ave.

Kennewick, WA 99336

M. Smith, Director

Savannah River Ecology Laboratory

Drawer E

Aiken, SC 29801

G. C. White

Group LS-6

Los Alamos National Laboratory

P.0. Box 1663

Los Alamos, NM 87545

F. W. Whicker

Radiology and Radiation Biology Department

Colorado State University

Fort Collins, CO 80521

ONSITE

6 DOE Richland Operations

R. E. Austin

P. Clark

D. R. Elle

R. E. Gerton

H. E. Ransom

M. W. Tiernan 
No. of

Copies

4 Rockwell Hanford Operations

D. S. Landeen

R. M. Mitche 11

D. L. Uhl

R. E. Wheeler

UNC Nuc lear Industries

J. J. Dorian

Westinghouse

R. B. Hall
No. of

Copies

83 Pacific Northwest Laboratory

K. E. Byers (3)

L. L. Cadwell (10)

L. E. Eberhardt (20)

R. E. Fitzner

E. E. Hanson (10)

H. V. Larson

M. A. Mckinney

T. L. Page

K. R. Price (20)

W. H. Rickard

L. E. Rogers

S. E. Rowe

M. J. Sula

B. E. Vaughan

M. L. Warner

W. R. Wiley

Publishing Coordination (2)

Technical Information (5)

Historical File--P. E. Bramson (2) 